This item was submitted to Loughborough's Research Repository by the author.

Items in Figshare are protected by copyright, with all rights reserved, unless otherwise indicated.

\title{
The long-term effects of invasive signal crayfish (Pacifastacus leniusculus) on instream macroinvertebrate communities
}

PLEASE CITE THE PUBLISHED VERSION

http://dx.doi.org/10.1016/j.scitotenv.2016.01.215

\section{PUBLISHER}

(C) Elsevier

\section{VERSION}

AM (Accepted Manuscript)

\section{PUBLISHER STATEMENT}

This work is made available according to the conditions of the Creative Commons Attribution-NonCommercialNoDerivatives 4.0 International (CC BY-NC-ND 4.0) licence. Full details of this licence are available at: https://creativecommons.org/licenses/by-nc-nd/4.0/

\section{LICENCE}

CC BY-NC-ND 4.0

\section{REPOSITORY RECORD}

Mathers, Kate, Richard P. Chadd, Michael J. Dunbar, Chris A. Extence, Jake Reeds, Stephen Rice, and Paul Wood. 2016. "The Long-term Effects of Invasive Signal Crayfish (pacifastacus Leniusculus) on Instream Macroinvertebrate Communities". Loughborough University. https://hdl.handle.net/2134/20353. 
The long-term effects of invasive signal crayfish (Pacifastacus leniusculus) on instream macroinvertebrate communities

Authors: Kate L. Mathers ${ }^{1}$, Richard P. Chadd ${ }^{2}$, Michael J. Dunbar ${ }^{3}$, Chris A. Extence $^{2}$, Jake Reeds ${ }^{2}$, Stephen P. Rice ${ }^{1}$, Paul J. Wood ${ }^{1}$.

${ }^{1}$ Department of Geography, Centre for Hydrological and Ecosystem Science, Loughborough University, Loughborough, UK.

${ }^{2}$ Environment Agency, Spalding, U.K.

${ }^{3}$ Environment Agency, Reading, UK.

\section{Author for Correspondence}

Kate Mathers

Centre for Hydrological and Ecosystem Science

Department of Geography

Loughborough University

Loughborough Leicestershire

LE11 3TU

UK

Email:- k.mathers@lboro.ac.uk 


\title{
The long-term effects of invasive signal crayfish (Pacifastacus leniusculus) on instream macroinvertebrate communities
}

Mathers, K.L., Chadd, R.P, Dunbar, M.J, Extence, C.A, Reeds, J., Rice, S.P. and Wood, P.J.

\begin{abstract}
Non-native species represent a significant threat to indigenous biodiversity and ecosystem functioning worldwide. It is widely acknowledged that invasive crayfish species may be instrumental in modifying benthic invertebrate community structure, but there is limited knowledge regarding the temporal and spatial extent of these effects within lotic ecosystems. This study investigates the long term changes to benthic macroinvertebrate community composition following the invasion of signal crayfish, Pacifastacus leniusculus, into English rivers. Data from long-term monitoring sites on 7 rivers invaded by crayfish and 7 rivers where signal crayfish were absent throughout the record (control sites) were used to examine how invertebrate community composition and populations of individual taxa changed as a result of invasion. Following the detection of non-native crayfish, significant shifts in invertebrate community composition were observed at invaded sites compared to control sites. This pattern was strongest during autumn months but was also evident during spring surveys. The observed shifts in community composition following invasion were associated with reductions in the occurrence of ubiquitous Hirudinea species (Glossiphonia complanata and Erpobdella octoculata), Gastropoda (Radix spp.), Ephemeroptera (Caenis spp.), and Trichoptera (Hydropsyche spp.); although variations in specific taxa affected were evident between regions and seasons. Changes in community structure were persistent over time with no evidence of recovery, suggesting that crayfish invasions represent significant perturbations leading to permanent changes in benthic communities. The results provide fundamental knowledge regarding non-native crayfish invasions of lotic ecosystems required for the development of future management strategies.
\end{abstract}

Keywords: non-native taxa, benthic invertebrates, community effects, seasonal sampling, persistent, spatial. 


\section{Introduction}

The spread of non-native taxa represents a significant threat to freshwater biodiversity and ecosystem functioning at a global scale (Sala et al., 2000; Lodge et al., 2000; Simberloff et al., 2013). The establishment of populations of invasive species within an ecosystem can severely disrupt the structure and functioning of native floral and faunal communities through direct predation, competition and displacement of native species, but also via indirect pathways and the decoupling of trophic dynamics (Nyström et al., 1996; Strayer, 2010; Gutierrez et al, 2014). Consequently, the influence of invasive taxa are often far reaching, with impacts ranging from the replacement of individual species to the modification of ecosystem processes (Riccardi, 2007; Jackson et al., 2014).

Crayfish represent some of the most successful and widely distributed invasive aquatic species worldwide, following either intentional introduction or accidental translocation (e.g. Hudina et al., 2012; Holdich et al., 2014; Kouba et al, 2014). They are one of the largest freshwater invertebrates, frequently dominating benthic faunal biomass where they occur (Lodge and Hill, 1994; Momot, 1995; Sousa et al., 2013). Even though many non-native crayfish replace an indigenous species, and thus frequently occupy similar ecological niches, invader effects may still be extensive if individuals reach a larger size and / or occur at greater population densities (Strayer, 2010; Gheradi et al. 2011), especially if this is associated with reduced predation pressure or if invaders are able to exploit a wider range of resources.

Crayfish display opportunistic polytrophic feeding habits, consuming algae, macrophytes, detritus, zoobenthos, fish and other crayfish (Momot et al., 1978; Lagrue et al., 2014; Ercoli et al., 2015a). Invasive crayfish may also act as ecosystem engineers through the alteration of detrital processing rates (Creed and Reed, 2004; Bobeldyk and Lamberti, 2008; Carvalho et al., 2016) and by changing the dominant algal cover on substrates (Creed, 1994; Matsuzaki et al., 2009). Studies documenting the effect of invasive crayfish in stream ecosystems have identified significant reductions in the biomass and richness of aquatic macrophytes (Lodge et al. 1994; Nyström et al., 2001), and aquatic invertebrates (Nyström et al., 1999; Stenroth and Nyström, 2003; Crawford et al., 2006; Nilsson et al., 2012; Ercoli et al., 2015b). 
Following invasion by crayfish, aquatic invertebrate community composition has been reported to shift towards more mobile taxa adapted to high flow velocities (e.g. Ephemeroptera species) at the expense of less mobile taxa such as Mollusca, Hirudinea and case-bearing Trichoptera species (Keller and Ruman, 1998; Parkyn et al., 1997; Dorn, 2013). The mobility of taxa, in addition to prey handling time, has been cited as key characteristics influencing the vulnerability of individual species associated with preferential predation (Ilheu and Bernado, 1993; Nyström and Perez, 1998; Nyström, 1999). However, many taxa display behavioural and life history changes in response to predator pressure through avoidance behaviours such as vertical migration or enhanced locomotion (Crowl and Covich, 1990; Alexander and Covich, 1991; Haddaway et al., 2015).

Indirect effects may also be evident within the ecosystem with a removal of macrophyte and algae cover affecting invertebrate populations through the loss of trophic resources and habitat availability (Lodge et al., 1994; Nyström et al., 1996). Similarly, a reduction of sedentary periphyton grazers (such as gastropods) and stimulated productivity through the excretion of nutrients may potentially benefit mobile grazers through the liberation of resources (Flint and Goldman, 1975; Charlebois and Lamberti, 1996). There have been suggestions that the composition of diet and feeding behaviour of crayfish varies with season (Goddard, 1988; Guan and Wiles, 1998), although evidence remains limited. Crayfish activity is seasonally variable being strongly regulated by water temperature (Gheradi et al., 1998; Bubb et al., 2004) as is the availability of macroinvertebrate prey (Allan, 1981).

As invasive crayfish extend their range, understanding their effects on biodiversity and ecosystem services is increasingly important for informing management strategies (Lodge et al., 2012; Jackson et al., 2014; Moorhouse et al., 2014). Despite the widely acknowledged threat that invasive crayfish pose, much of the research to date has been focused on lentic ecosystems, whilst the impact on stream communities has been poorly quantified in many regions (Stenroth and Nyström, 2003; Pysek et al., 2008; Lodge et al., 2012). The majority of studies have investigated the short-term effects of invasive crayfish at site or reach scales via small-scale in-situ enclosure experiments or through the use of ex-situ laboratory mesocosms typically over one season (e.g., Parkyn et al., 1997; Stenroth and Nyström, 2003; Magoulick, 2014; see Twardochleb et al, 2013 for a meta-summary 
of all published invasive crayfish studies). Other studies have employed in-situ sampling over a limited duration (1 -12 months) where invading crayfish populations are already well established (e.g., Crawford et al., 2006). Short term experiments provide mechanistic insights into crayfish - community or individual population interactions. However, it is also necessary to investigate the long-term and large scale effects of invasive crayfish in order to determine whether they are persistent and if the effects vary spatially, temporally or seasonally. Long- term studies also provide the opportunity to quantify the extent of invasion effects that cannot be captured though experimental mesocosm studies (Wilson et al., 2004; McCarthy et al., 2006).

This study examines the long-term effects of the invasive signal crayfish, Pacifastacus leniusculus (Dana) on macroinvertebrate community composition and individual taxa within lowland rivers in England (UK) during spring and autumn seasons. Signal crayfish (P.leniusculus) are endemic to North America and have been introduced to over 20 countries in Europe. They are considered to be one of the most prevalent non-native crayfish species in Europe, with widespread and abundant populations now established across the UK (Kouba et al., 2014; Holdich et al., 2014). Unlike previous studies, the effect of invasive crayfish is investigated using multiple regions and catchments before and after invasion, and in direct comparison with control sites where long-term monitoring has not recorded the presence of $P$. leniusculus. Specifically we addressed the following questions:

1) Does the invasion of $P$. leniusculus lead to significant changes in benthic macroinvertebrate community composition in lotic ecosystems?

2) Is the effect of $P$. leniusculus invasion on macroinvertebrate community composition spatially extensive (is the effect evident over different biogeographical ranges of lowland England) and do the effects persist over time (multiple years)?

3) Are the implications of $P$. leniusculus invasion seasonally dependent or are the effects on the macroinvertebrate community composition persistent and evident all year round?

4) Are the same lotic taxa identified in previous studies of invasion by $P$. leniusculus (e.g. sensu Guan and Wiles, 1998; Usio and Townsend, 2004; 
Crawford et al., 2006) responsible for the changes observed in rivers in the current investigation?

\section{Materials and methods}

\subsection{Datasets characterised}

Following preliminary consultation with staff from a statutory environmental monitoring authority, the Environment Agency of England, macroinvertebrate community data from three English regions were extracted from the Environment Agency 'BIOSYS' database. The database covers sites across England and contains long term biomonitoring (benthic macroinvertebrate) records for over 27000 sites. To allow comparison between sites invaded by $P$. leniusculus and control sites, those selected for the study shared similar characteristics with the exception of invasion by crayfish. This aimed to minimise the influence of any potential confounding factors on the analysis. All sites selected had to fulfil the following criteria: i) records extended over multiple years with a minimum of 5-years macroinvertebrate community data prior to invasion by $P$. leniusculus or in the case of control sites 5-years before the average date rivers in the region were invaded (the dataset was subsequently divided into spring and autumn survey periods); ii) sites did not support a native crayfish population during any of the time series; iii) sites were not subject to other recent invasions and; iv) sites were not subject to other significant anthropogenic stressors such as water abstraction, flow regulation or impaired water quality. Criterion iii) was relaxed for the non-native gastropod Potamopyrgus antipodarum (Gastropoda: Hydrobiidae) because this species is widely distributed across most regions of the UK since its introduction over a century ago (Ponder, 1988) but is not thought to have a significant influence on freshwater invertebrate communities in most European streams (Murria et al., 2008).

Data from three regions formed the basis for the analysis, encompassing natural variability in community composition across England (East, South East and North West England; Figure 1). The regions were selected to reflect natural biogeographical, geological and hydrological variability across England, thus incorporating the diverse regional variability of lowland river systems. Following screening of the data, a total of 7 'invaded' and 7 'control' lowland rivers were identified (Table 1). Rivers were selected to have broadly comparable physical characteristics within the individual regions (channel size, discharge, water chemistry, 
altitude and geology). Rivers in South-East England are predominately characterised by chalk deposits, those in East England by mudstones and those in the North West by sedimentary sandstone and igneous rocks. The characteristics of the rivers employed by region are shown in Table 2. Rivers utilised in the study were not heavily managed or regulated and consequently physical and hydrological characteristics did not change during the study period. In addition, electrofishing surveys conducted by the Environment Agency of England indicate no major changes in fish populations over time in all rivers employed.

Table 1. Rivers included in the long-term analysis. Control sites were assigned a nominal date to allow comparison with invaded sites (denoted in bold italics) based on the average date of invasion for the respective region (Note - control sites were free from crayfish during the entire study period).

\begin{tabular}{lcccc}
\hline River & $\begin{array}{c}\text { English } \\
\text { Region }\end{array}$ & $\begin{array}{c}\text { Duration of } \\
\text { record }\end{array}$ & $\begin{array}{c}\text { Control / } \\
\text { Invaded? }\end{array}$ & Invasion point \\
\hline Gwash & East & $1989-2013$ & Invaded & 1996 \\
Nene & East & $1991-2013$ & Invaded & 1998 \\
Chater & East & $1990-2013$ & Control & $\mathbf{1 9 9 7}$ \\
Eyebrook & East & $1990-2013$ & Control & $\mathbf{1 9 9 7}$ \\
Harrop Brook & North West & $1990-2013$ & Invaded & 1996 \\
Torkington Brook & North West & $1990-2004$ & Invaded & 1998 \\
Glossop Brook & North West & $1990-2013$ & Invaded & 1997 \\
Bollin & North West & $1990-2013$ & Control & $\mathbf{1 9 9 7}$ \\
Sett & North West & $1986-2013$ & Control & $\mathbf{1 9 9 7}$ \\
Ver & South East & $1990-2013$ & Invaded & 2002 \\
Rib & South East & $1975-2013$ & Invaded & 2006 \\
Gade & South East & $1983-2013$ & Control & $\mathbf{2 0 0 3}$ \\
Mimram & South East & $1975-2013$ & Control & $\mathbf{2 0 0 3}$ \\
Ash & South East & $1977-2013$ & Control & $\mathbf{2 0 0 3}$ \\
\hline
\end{tabular}


Table 2. Summary of selected abiotic characteristics (mean values) of rivers employed in analysis by region. The rivers examined in the study were not heavily managed or regulated and consequently physical and hydrological characteristics did not change significantly during the study period.

\begin{tabular}{ccccccc}
\hline & $\begin{array}{c}\text { North } \\
\text { West } \\
\text { invaded }\end{array}$ & $\begin{array}{c}\text { North } \\
\text { West } \\
\text { control }\end{array}$ & $\begin{array}{c}\text { South } \\
\text { East } \\
\text { invaded }\end{array}$ & $\begin{array}{c}\text { South } \\
\text { East } \\
\text { control }\end{array}$ & $\begin{array}{c}\text { East } \\
\text { invaded }\end{array}$ & $\begin{array}{c}\text { East } \\
\text { control }\end{array}$ \\
\hline Altitude (m a.o.d) & 138 & 199 & 59 & 73 & 86 & 63 \\
Depth (m) & 0.13 & 0.11 & 0.25 & 0.16 & 0.22 & 0.1 \\
Width (m) & 3.67 & 3 & 7.5 & 4.67 & 3.33 & 4.5 \\
Discharge (m $\left.\mathbf{m}^{3} / \mathbf{~ s e c}\right)$ & 0.62 & 0.31 & 0.46 & 0.31 & 0.36 & 0.46 \\
Alkalinity $\mathbf{~ m g ~ L}^{-1}$ & 79 & 47 & 265 & 262 & 212 & 201 \\
\hline
\end{tabular}

All benthic invertebrate samples were collected using the Environment Agency's standard sampling protocol comprising a 3-minute 'kick-sample', which encompasses all available habitats, and an additional 1-minute, detailed hand search (Murray-Bligh, 1999). This sampling strategy has provided an effective means of detecting temporal changes in invertebrate communities of English and Welsh rivers previously (Monk et al., 2008; Durance and Ormerod, 2009). Data were analysed on a seasonal basis (Spring, March-May and Autumn, SeptemberNovember) to enable the determination of consistent trends. The data-set comprised 530 samples in total ( 255 and 275 from invaded and control samples respectively) with the majority of samples collected between 1990 and 2013 (three sites had data series extending back to the 1970's and an additional three further sites had data from the mid 1980's) and a total of 596 taxa were recorded. 


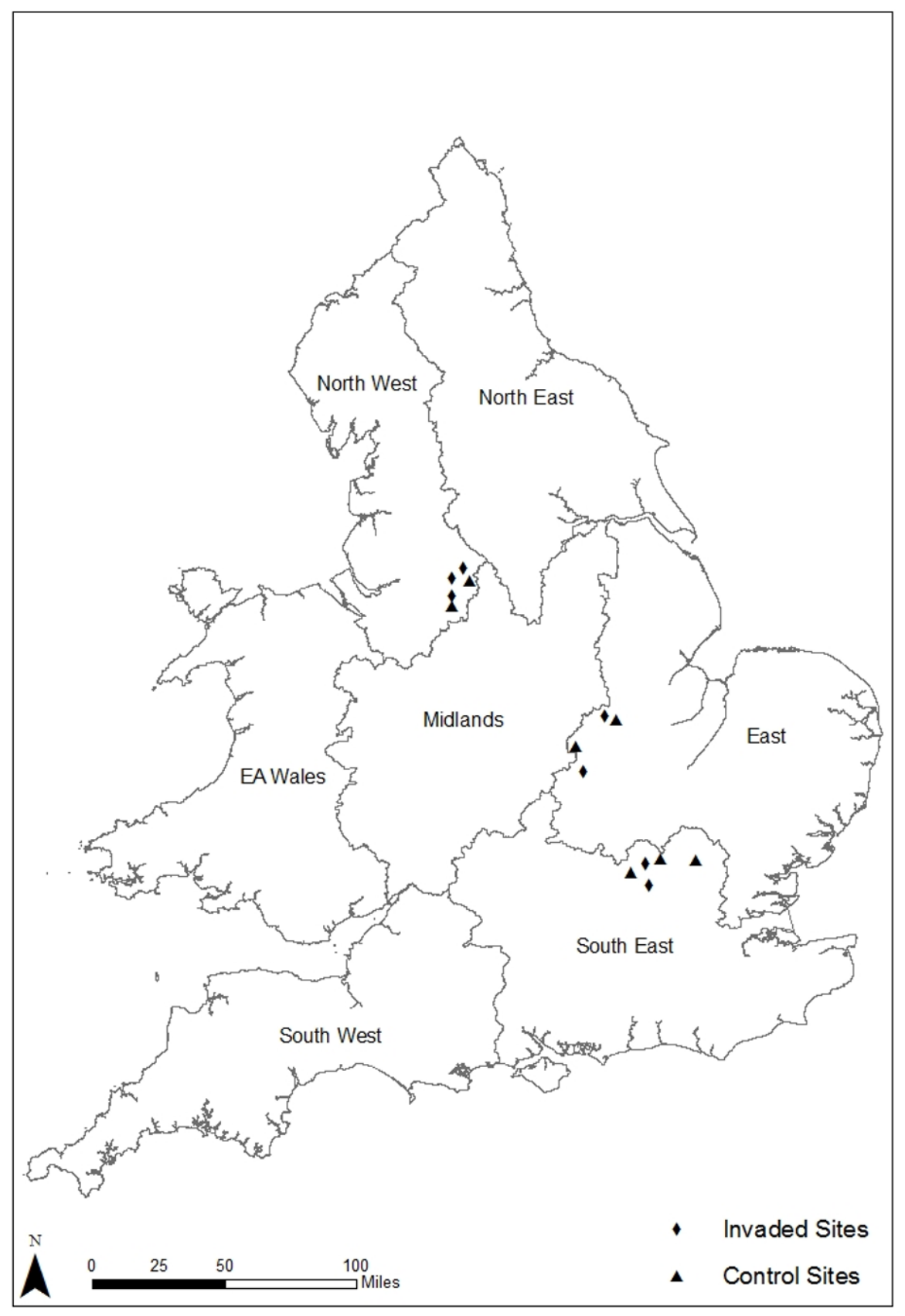

Figure 1. Site locations of the long term macroinvertebrate biomonitoring records employed from the South East, North West and East regions of England.

Given the length of macroinvertebrate community records many of the faunal lists comprised mixed taxonomic levels of identification. As a result the lowest possible taxonomic level available across the three regions was used. In the majority of instances this meant genus level data were utilised, although species level data were available for a number of taxa. Diptera larvae were resolved to family level and Hydracarina to order level throughout the series. Due to variations in the way in which abundance data were recorded over time, reflecting a shift from abundance 
classes on a $33^{\text {rd }}$ percentile logarithmic scale to abundances on standard logarithmic scales (and real counts for single digit abundances), abundance data were standardised into ordinal classes (Durance and Ormerod, 2009) to enable comparison over the whole series $(1=\leq 9,2=10-32,3=33-99,4=100-332,5$ $=333-999,6=\geq 1000$ ).

\subsection{Data analysis}

Changes to macroinvertebrate community composition were examined via nonmetric multidimensional scaling (NMDS) using Bray-Curtis similarity coefficients. Data were categorised into four groups: i) control - before invasion, ii) control - after invasion, iii) invaded - before invasion and; iv) invaded - after invasion. For invaded sites the approximate date of invasion was determined by the first occurrence of $P$. leniusculus in the historical faunal series. No density data was available for the sites because routine sampling of crayfish populations is not a standard Environment Agency biomonitoring practice following invasion. Detecting signal crayfish is difficult due to their high mobility (Gladman et al., 2010) and there are currently no methods of determining crayfish populations below a density of $0.2 \mathrm{~m}^{-2}$ (Peay, 2003). For the kick-net samples utilised in this study, it is likely that the detection limit is higher, probably approaching a density of $1.0 \mathrm{~m}^{-2}$. Consequently for all sites employed in this study, crayfish densities would be significant, although some variation by sites and through time is likely. In addition, it is important to acknowledge that signal crayfish may have been present at the study sites for a several years prior to formal detection.

Control sites were divided into two periods (before invasion and after invasion) based on the mean date of invasion for the invaded rivers in the respective region (1997 for East; 1997 for North West; and 2003 for South East). The assignment of a nominal date allowed a direct comparison between the control and invaded sites over the same time-period and also provided a means of assessing whether there were temporal shifts in invertebrate community composition not associated with crayfish invasion. This approach was taken as previous long-term analyses of UK data sets have revealed changes in community composition associated with drought (Monk et al., 2008), modification of channel morphology (Dunbar et al., 2010) and improvements in water quality (Durance and Ormerod, 2009). 
A One way ANOSIM (Analysis of Similarities) was used to examine differences in the communities amongst the control and invaded rivers before and after 'invasion'. Both $P$ and $R$ ANOSIM values were examined, with $R$ values $>0.75$ indicating strong separation amongst groups, $R=0.75-0.25$ indicating separate groups with overlapping values and $R<0.25$ as barely distinguishable groups (Clarke and Gorley, 2006). Taxa contributing to the differentiation of communities within individual regions and for river group (control and invaded) were identified through the application of the similarity percentage (SIMPER) with a selection of these examined in further analysis according to criteria described below. Preliminary NMDS analysis indicated strong differences among regions for macroinvertebrate community composition and as a result subsequent analyses were conducted on a regional basis. ANOSIM indicated significant differences for all pairwise comparisons of regions in both seasons; all $P$ values $<0.001$ and $R$ values $>0.75$. To assess temporal changes in community composition and determine if macroinvertebrate communities demonstrated recovery following invasion, temporal trajectories of changes in assemblage composition were plotted for each river and season. All regional NMDS analyses were performed in PRIMER Version 6.1.16 (PRIMER-E Ltd, Plymouth, UK).

To assess changes in individual taxa associated with crayfish invasion, taxon occurrence (presence or absence) amongst the control and invaded rivers both before and after invasion were examined. Nine taxa (3 Mollusca, 2 Ephemeroptera, 2 Hirudinea, 1 Trichoptera and 1 Crustacean) were selected for further analysis on the basis of the following criteria: i) identified as driving community differentiation in a number of regions through application of SIMPER in analyses outlined above and / or ii) widely cited in previous studies of invasive crayfish effects in lotic systems (e.g. Keller and Ruman, 1998; Haddaway et al., 2014; Moorhouse et al., 2014) and; iii) abundant in all regions and sites during the study period.

Generalised linear mixed models (GLMMs) were fitted to each taxon for each season (Spring and Autumn) using a binomial error distribution. Models were fitted to presence / absence data using the glmmADMB version 0.8.1 package (Fournier et al. 2012, Skaug et al., 2014 ) in R version 3.1.2 (R development Core Team, 2014). The final model was built using region, treatment (control or invaded) and time period 
(before or after invasion) as terms. Monitoring site was specified as a random effect to reflect that taxon occurrence through time at individual sites will be correlated. To assess the effect of crayfish on the occurrence of specific taxa, the significance of the interaction term (time period $x$ treatment) was examined. This enabled determination of whether taxa changes over time occurred in both invaded and control rivers or if the effect was confined to those where $P$. leniusculus occurred. Results were visualised by predicting probabilities of occurrence for each Before After - Control - Invaded combination calculated from the GLMM on the linear predictor scale and transformed to the response scale using the inverse-logit function to enable the direction and trends of change to be ascertained. Standard errors for predictions were calculated on the linear predictor scale by multiplying the model matrix for each Before -After- Control - Invaded combination by the variancecovariance matrix for the fixed-effect parameter estimates. These were converted to confidence intervals (+/- $2 \mathrm{SE}$ ) on the same scale and similarly back-transformed. Visual predictions of the Before - After - Control - Invaded relationship are based upon an 'average' site as a function of the global GLMM.

\section{Results}

\subsection{Community composition}

Non-metric Multi-Dimensional Scaling (NMDS) ordination diagrams for all three regions (South East, North West and East England) indicated distinct clusters of macroinvertebrate communities following crayfish invasion for both Spring and Autumn seasons (Figure 2). In most instances, each of the regional diagrams indicated similar community composition between control and invaded sites prior to crayfish colonisation. Following colonisation, the invaded and control sites formed distinct groups, indicating a change in community composition at both control and invaded sites compared to the period preceding crayfish invasion.

The degree of separation between the groups using Analysis of Similarity (ANOSIM) indicated highly significant differences for all pairwise comparisons of groups for South East England (all $P<0.02$ ), North West (all $P<0.002$ ) and East England (all $P<0.001)$. $R$ values indicate that before colonisation, control and invaded groups were barely distinguishable in the South East $\left(R_{s}=0.116\right.$ and $R_{a}=0.16$ for both spring and autumn respectively) and in the East during spring months $\left(R_{s}=0.130\right)$. 
During autumn months for East England $\left(R_{a}=0.280\right)$ and for both seasons in North West England $\left(R_{s}=0.636\right.$ and $\left.R_{a}=0.344\right)$ the degree of similarity between invaded and control sites before invasion was less strong but was still evident. Following colonisation by crayfish, invaded and control groups demonstrated a higher degree of separation in all three regions and were strongly separated in the North West $\left(R_{S}\right.$ $=0.886$ and $R_{a}=0.861$ ) and were separated but overlapping within the South East $\left(R_{s}=0.512\right.$ and $\left.R_{a}=0.421\right)$ and East $\left(R_{s}=0.457\right.$ and $\left.R_{a}=0.609\right)$.
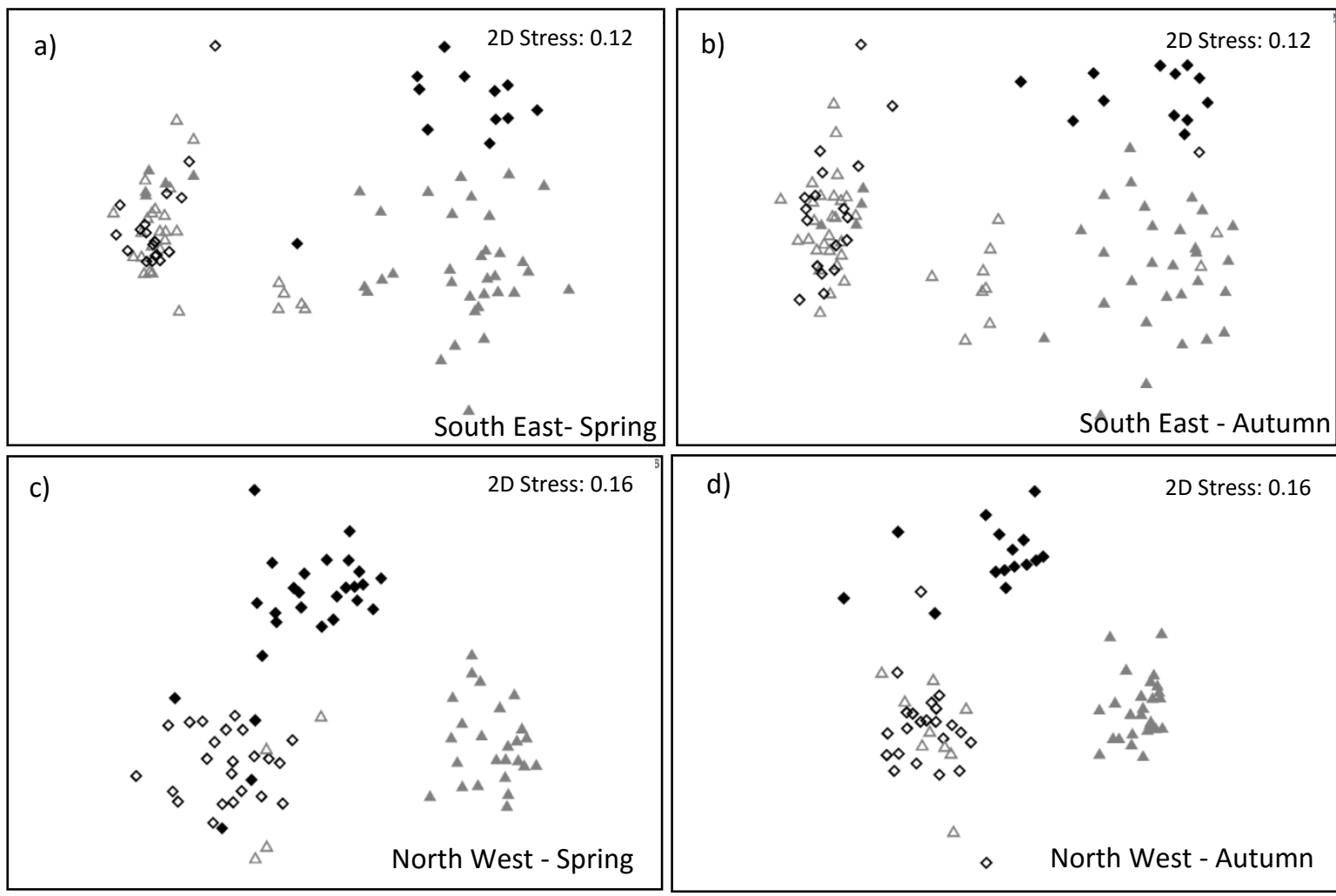

d)

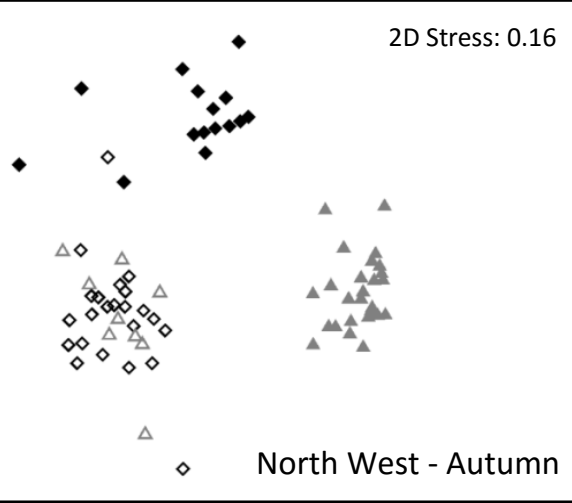

e)
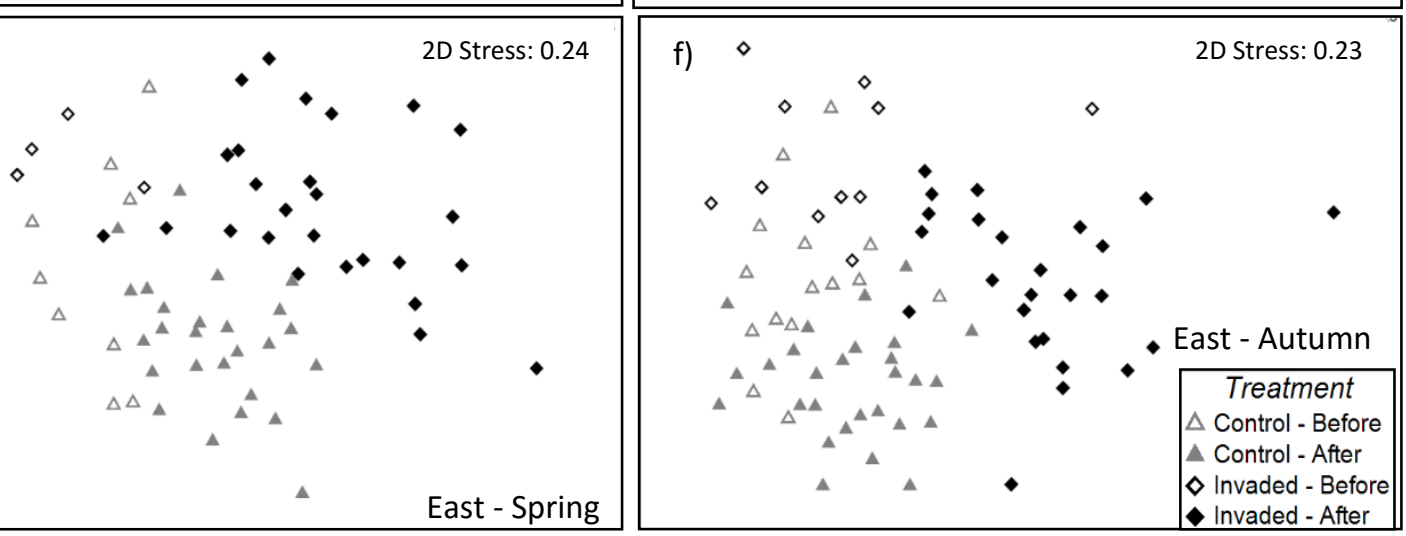

Figure 2. NMDS seasonal ordinations of benthic macroinvertebrate community data using the BrayCurtis similarity coefficients for spring and autumn for: a) \& b) South East; c) \& d) North West and; e) \& f) East England 
Temporal trajectories of macroinvertebrate community change were observed for both invaded and control rivers (Figures 3 and S1). Within invaded rivers, the community demonstrated clear changes in structure directly after invasion. Community changes were also evident in control rivers over the time period but these were different to those recorded for invaded sites and very little overlap was evident after the invasion point (IP on Figure 3). Prior to invasion, control and invaded river trajectories demonstrated considerable overlap with pathways intersecting on a number of occasions. Following the invasion point, trajectories of change for both control and invaded rivers remained discrete, with no similarities apparent or marked changes in trajectory paths (to indicate recovery) evident for invaded sites.

The taxa primarily responsible for community composition changes within invaded rivers (before vs after), as identified by the similarity percentage (SIMPER), differed regionally as a function of natural biogeographic differences in community composition, although several taxa were common to two or more regions: 3 regions Gammarus pulex, Hydropsyche spp., Potamopyrgus antipodarum, Baetis spp. and Hydracarina and; 2 regions - Sphaeriidae, Simuliidae and Elmidae (Table 3). Where several species were identified by SIMPER from the same genus within or between regions, these were combined to enable analysis of the most ubiquitous taxa across regions through application of the GLMM (e.g. Hydropsyche spp., Baetis spp., Caenis spp. and Radix spp. contained several species identified by SIMPER). Regions also displayed some seasonal differences in the taxa identified as driving changes, with some taxa identified to be driving community dissimilarity in one season but not the other (e.g. Planorbidae, Asellus aquaticus, Heptageniidae). Taxa identified to be driving changes in control river communities over time are presented as supplementary material (Table $\mathrm{S} 1$ ). 

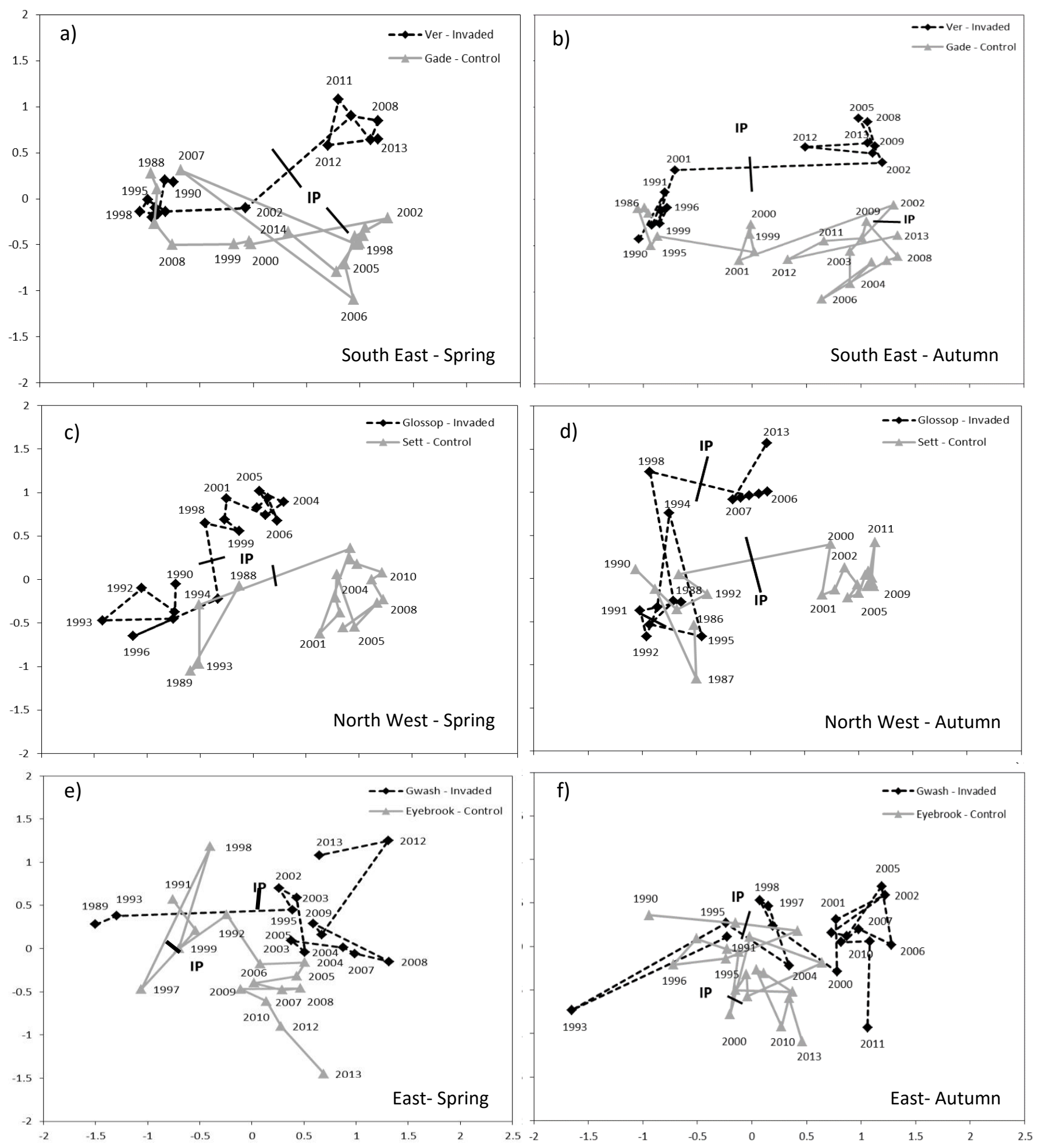

Figure 3. NMDS temporal ordinations of benthic macroinvertebrate community data. Individual rivers are linked by temporal trajectories of change during the sampling period. Plots represent pairwise comparisons of invaded river(s) and control river(s) by region and season for: a) \& b) South East rivers Ver and Gade; c) \& d) North West rivers Glossop and Sett and; e) \& f) East England rivers Gwash and Eyebrook. Other rivers are presented in supplementary material (Figure S1). The invasion date for both invaded and control rivers are denoted using the abbreviation IP (Invasion Point).

Control rivers are symbolised by a solid grey line and invaded rivers by a black dashed line. 
Table 3. Summary of the top 10 invertebrate taxa (ranked percentage dissimilarity) as identified by SIMPER analysis as most strongly influencing site dissimilarity of community composition before and after crayfish invasion (invaded rivers) for the different regions and seasons. Total change in abundance following invasion indicated in parentheses (+/-), and season (Spring = S, Autumn = A). Where no letter is provided taxa identified for both seasons. Note for South East and North West.

\begin{tabular}{|c|c|c|}
\hline East & South East & North West \\
\hline Hydropsyche spp. (-) & Hydropsyche spp. (-) & Hydropsyche spp. (+) \\
\hline Glossiphonia complanata (-) & Baetis spp. (+) & Baetis spp. (+) \\
\hline Sphaeriidae (-) & Sphaeriidae (-) & Gammarus pulex (+) \\
\hline Gammarus pulex (+) & Gammarus pulex (+) & Chironomidae (+) \\
\hline Caenis spp. (-) & Valvata piscinalis (-) & Elmidae $(+A)$ \\
\hline Radix spp. (-) & Potamopyrgus antipodarum (+) & Ecdyonurus spp. (-) \\
\hline Baetis spp. (+) & Elmidae (-) & Hydracarina (-) \\
\hline Potamopyrgus antipodarum $(-\mathrm{S},+\mathrm{A})$ & Leptoceridae (-) & Simuliidae (-) \\
\hline Ancylus fluviatilis (-) & Hydracarina (-) & Potamopyrgus antipodarum (-A) \\
\hline \multirow[t]{3}{*}{ Hydracarina (-) } & Simuliidae $(-A)$ & Asellus aquaticus (- A) \\
\hline & Planorbidae (- S) & Heptageniiidae $(+S)$ \\
\hline & & Empididae $(+S)$ \\
\hline
\end{tabular}

\subsection{Taxon-specific responses}

Results presented below are for the GLMM model based on presence / absence of nine select taxa by individual season based on a global model (all regions). Results indicate if changes in taxa occurrence over time were common across all sites (both control and invaded) or if they were confined to invaded sites and therefore could be attributed to crayfish invasion.

\subsubsection{Spring}

The prevalence of the leech Glossiphonia complanata $(P=0.024)$ declined significantly following crayfish invasion whilst the occurrence of Erpobdella octoculata did not differ significantly compared to control sites $(P=0.161)$, although a reduction in its occurrence was evident (Figure 4). The occurrence of the bivalve family Sphaeriidae declined following invasion but this was not statistically significant when compared to control sites $(P=0.228)$. The prosobranch gastropod mollusc $P$. antipodarum $(P=0.320)$ demonstrated no significant changes in occurrence associated with crayfish invasion whilst the pulmonate gastropod Radix spp. declined significantly $(P=0.003$; Figure 4$)$. Mayflies from the genus Caenis displayed reduced prevalence following invasion but this was not significant relative to control sites $(P=0.165)$. The mayfly Baetis spp. and amphipod $G$. pulex displayed no change in prevalence $(P=0.120$ and $P=0.060$ respectively) following crayfish invasion with their occurrence remaining high (Figure 4). The occurrence of the 
caddisfly nymph, Hydropsyche spp., reduced significantly $(P=0.010)$ following crayfish invasion compared to control sites (Figure 4).

Glossiphonia complanata

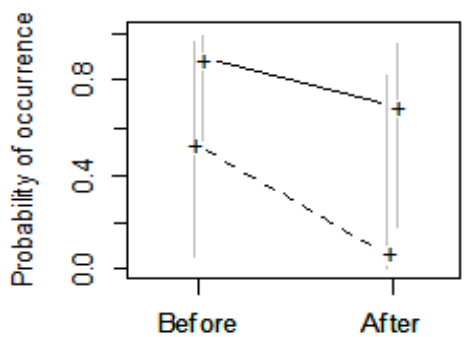

Sphaeriidae

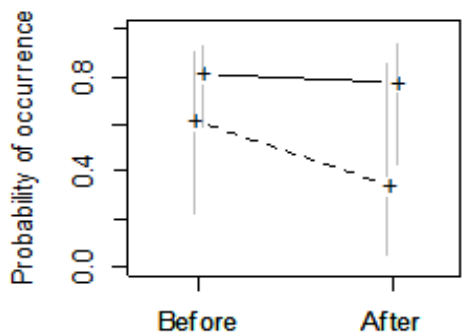

Baetis spp.

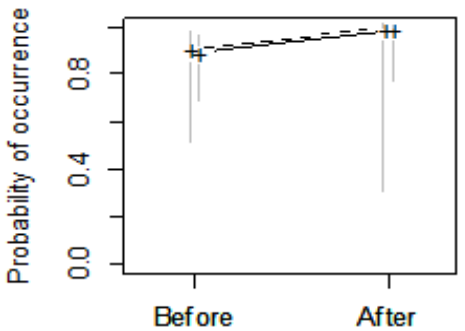

Erpobdella octoculata

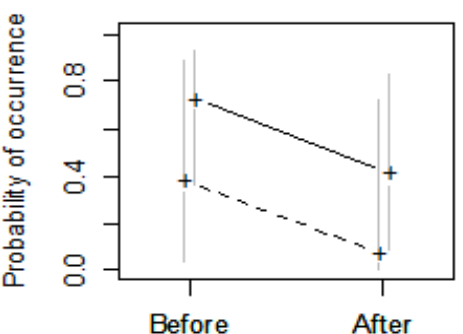

Radix spp.

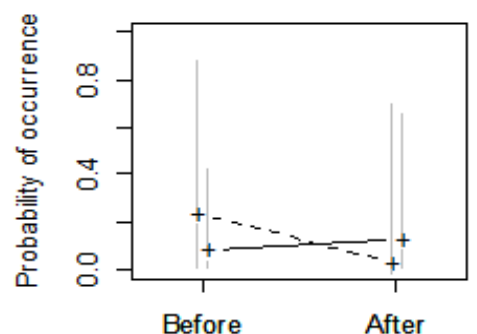

Gammanus pulex

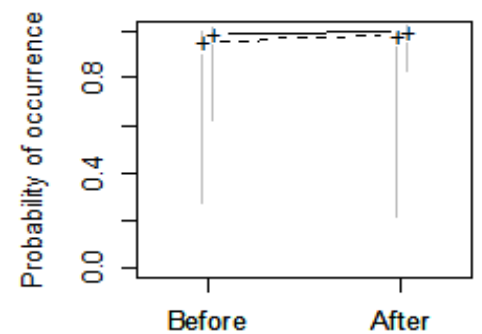

- Control --- Invaded
Potamopyrgus antipodarum

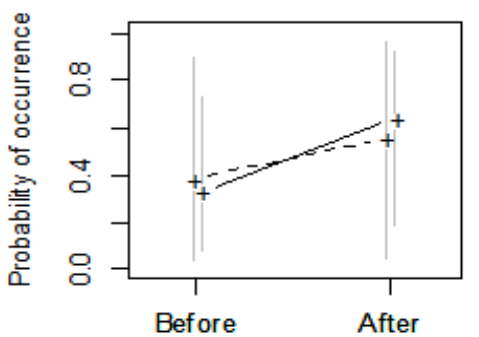

Caenis spp

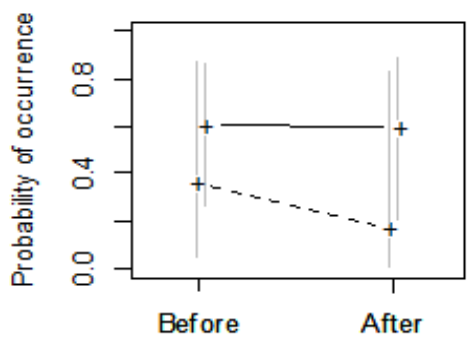

Hydropsyche spp

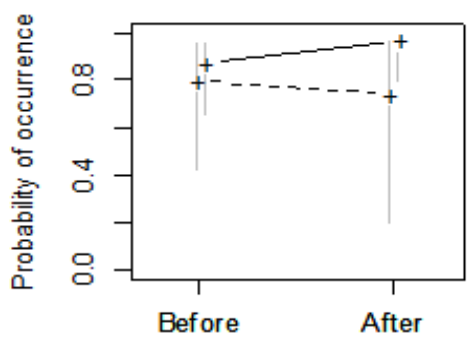

Figure 4. Predictions of average probability of occurrence for individual taxa with confidence intervals for each combination of before, after, control and invaded factor based on spring months (March May). Predictions made for nine selected taxa using the Generalised Linear Mixed Model approach described in the text. Predictions of occurrence for each taxon are made using the global GLMM dataset (all regions) with predictions representing an average of all sites.

3.2.2 Autumn The occurrence of the leech species G. complanata, E. octoculata, and the gastropod Radix spp. (all $\mathrm{P}<0.001$ ) declined significantly following crayfish invasion relative to control sites (Figure 5). Both Sphaeriidae and $P$. antipodarum demonstrated no change in occurrence following crayfish invasion $(P=0.840$ and $P$ $=0.225$ respectively; Figure 5). Insect larvae within the order Ephemeroptera displayed contrasting responses following crayfish invasion. The prevalence of 
Baetis spp. did not differ significantly over time at either control or invaded sites $(\mathrm{P}=$ $0.700)$ whilst Caenis spp. were significantly less common following crayfish invasion $(P=<0.001$; Figure 5). The amphipod G. pulex $(P=0.281)$ demonstrated no significant changes following invasion, whilst the Trichoptera Hydropsyche spp. declined at invaded sites $(P=0.028$; Figure 5$)$. All statistical significance levels and standard error values for the Before-After-Control-Invaded interaction effect for each taxon are shown in Table 4.
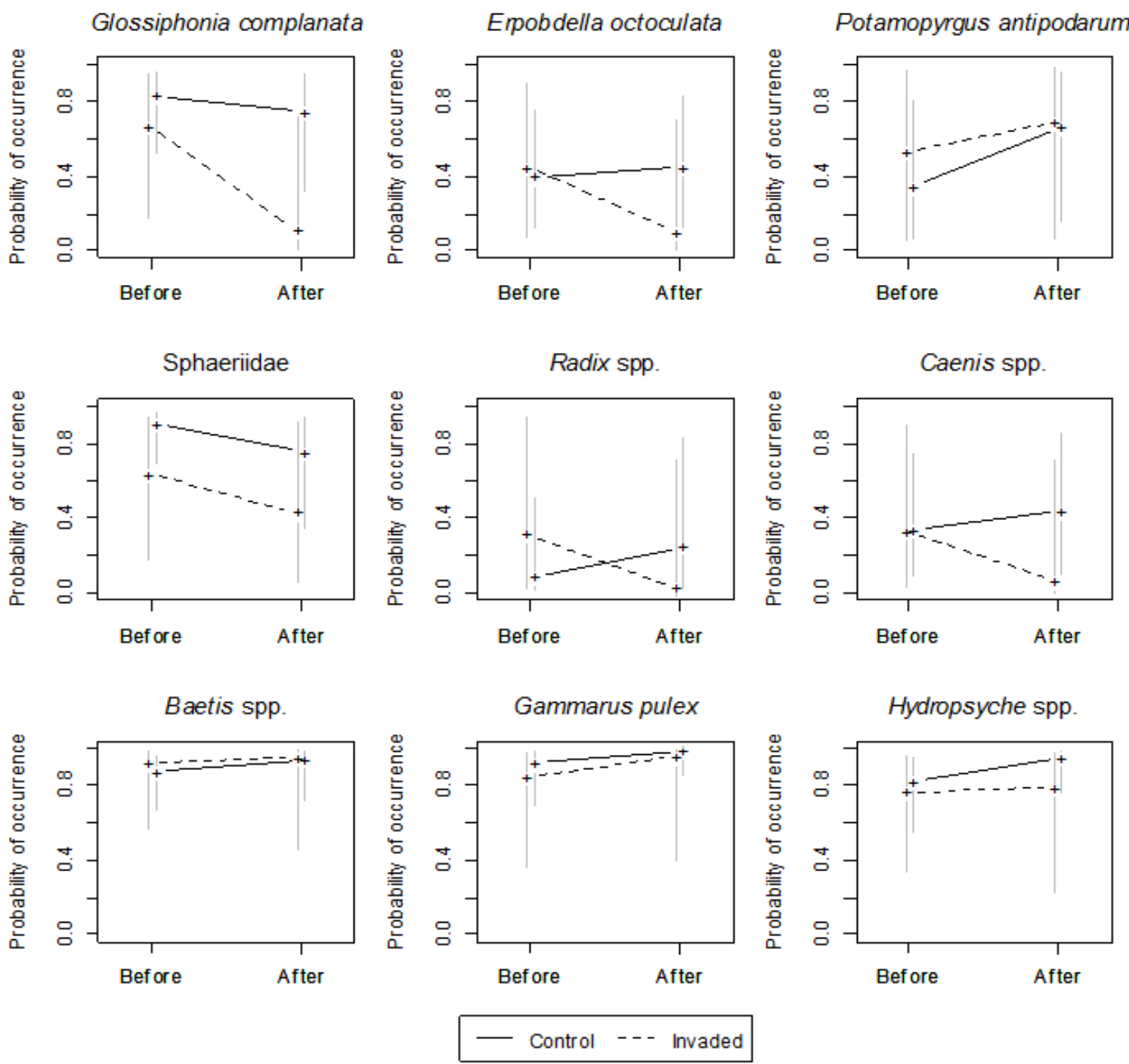

Figure 5. Predictions of average probability of occurrence for individual taxa with confidence intervals for each combination of before, after, control and invaded factor based on autumn months (September - November). Predictions made for nine selected taxa using the Generalised Linear Mixed Model approach described in the text. Predictions of occurrence for each taxon are made using the global GLMM dataset (all regions) with predictions representing an average of all sites. 
Table 4. Summary values for the Before-After-Invaded-Control interaction effects from the GLMM predictions for each taxon for spring and autumn. Significant terms are denoted in bold.

\begin{tabular}{|c|c|c|c|c|c|c|}
\hline \multirow[b]{2}{*}{ Taxon } & \multicolumn{3}{|c|}{ Spring } & \multicolumn{3}{|c|}{ Autumn } \\
\hline & $\begin{array}{l}\text { Standard } \\
\text { Error }\end{array}$ & Z-Value & P Value & $\begin{array}{l}\text { Standard } \\
\text { Error }\end{array}$ & Z-Value & P Value \\
\hline \multicolumn{7}{|l|}{ Hirudinea } \\
\hline Glossiphonia complanata & 0.978 & -2.26 & 0.024 & 0.784 & -3.57 & $<0.001$ \\
\hline Erpobdella octoculata & 0.791 & -1.40 & 0.161 & 0.657 & -3.42 & $<0.001$ \\
\hline \multicolumn{7}{|l|}{ Mollusca } \\
\hline Potamopyrgus antipodarum & 0.765 & -0.99 & 0.320 & 0.730 & -1.21 & 0.225 \\
\hline Sphaeriidae & 0.685 & -1.21 & 0.228 & 0.692 & 0.20 & 0.840 \\
\hline Radix spp. & 1.109 & -2.91 & 0.003 & 1.151 & -4.65 & $<0.001$ \\
\hline \multicolumn{7}{|l|}{ Ephemeroptera } \\
\hline Caenis spp. & 0.744 & -1.39 & 0.165 & 0.774 & -3.61 & $<0.001$ \\
\hline Baetis spp. & 1.518 & 0.12 & 0.908 & 0.903 & -0.38 & 0.700 \\
\hline \multicolumn{7}{|l|}{ Trichoptera } \\
\hline $\begin{array}{l}\text { Hydropsyche spp. } \\
\text { Crustacean }\end{array}$ & 0.838 & -2.55 & 0.01 & 0.703 & -2.20 & 0.028 \\
\hline Gammarus pulex & 1.557 & -1.88 & 0.06 & 1.004 & -1.08 & 0.281 \\
\hline
\end{tabular}

\section{Discussion}

\subsection{Invertebrate community responses to $P$. leniusculus invasion}

The results from this study provide strong evidence that invasive signal crayfish affect invertebrate community composition in lowland rivers. All three regions examined experienced marked changes in benthic community composition following invasion when compared to both pre-invasion conditions and control sites. The effect on macroinvertebrate communities in all three regions was seasonally consistent, being strongest during autumn months, but were also evident in spring months. Crayfish movement and growth is strongly driven by water temperature, with activity typically peaking during summer months (Sousa et al., 2013; Johnson et al., 2014). Consequently, stronger effects on macroinvertebrate communities during the autumn months were expected, as these samples typically occur at the height or toward the end of crayfish activity (notably directly after the breeding season). Slight differences in the taxa driving the community changes between seasons were also evident, suggesting that seasonal heterogeneity of prey availability, and thus preferential predation, is a key process determining the effects of invaders on macroinverterbrate communities (Xu et al., 2012).

In each of the regions examined, the community composition of control and invaded sites diverged when compared with samples from the pre-invasion period. In addition, control sites also displayed a shift in community composition temporally, but these 
changes were different to those recorded in the invaded rivers, suggesting the presence of a widespread stressor across all sites. During the study period, England experienced highly variable hydro-climatological conditions with a series of high magnitude droughts and prolonged periods of low flows in 1989-1992, 1995-1997 and 2004-2006, with the latter years focussed in the South East of England (Marsh et al., 2007; Hannaford and Buys, 2012). With the exception of one site, the River Ver in South East region, the invasion by $P$. leniusculus occurred during or directly after one of these high magnitude low flow periods known to have resulted in community changes across England (Wright et al., 2004; Monk et al., 2008; Laize et al., 2014; Worrall et al., 2014). These periods resulted in changes to community composition at all of the sites examined and provides evidence to explain the longterm changes observed at control sites in addition to those at sites invaded by $P$. leniusculus. However, it is important to note that the invasion of sites in this study is likely to predate the point in which they were recorded in biomonitoring samples in some instances. As a result, the drought conditions may have facilitated the expansion of non-native crayfish populations. The interaction between flow regime / hydrological variability and invasive taxa requires further detailed examination. Evidence suggests that crayfish populations are not severely affected during high magnitude drought events (Jones and Bergey, 2007; Distefano et al., 2009; Dyer et al., 2015) and consequently invasive crayfish may have strong effects on stream ecosystems irrespective of the occurrence of hydrological stressors (Magoulick, 2014).

\subsection{Temporal and spatial persistence of crayfish invasion effects}

Results from this study indicate that crayfish invasions have long term effects on rivers across a broad biogeographical range with invasion effects not dependent on a specific physical setting. Community impacts are evident and have persisted within all of the regions despite being characterised by different lithologies, flow regimes and habitat characteristics. Despite control and invaded rivers representing discrete communities following invasion in all sites, the degree of separation varied between regions. The effect of invasive crayfish is heavily dependent on original community composition as this dictates which species are preferentially predated. Communities which support abundant populations of taxa susceptible to predation will therefore be more severely affected following invasion events. We are aware of only two other 
studies which have examined the long-term impact of invasive crayfish on benthic communities thus far (Wilson et al., 2004; McCarthy et al., 2006), however both were focussed on lentic systems in North America over limited spatial scales. Both studies reported significant modifications to benthic community composition with dramatic long term and potentially irreversible effects on the ecosystem evident as a whole. Results from the current investigation, provide the first quantitative evidence that crayfish invasion effects within rivers are long-standing and persist once the invading population has become established.

Temporal trajectories of community change indicated that shifts occurred directly after invasion in the majority of rivers examined. As the precise date of invasion is not known for these rivers (IP indicates the point they were detected in routine benthic samples), it is likely that densities would have reached significant numbers before being formally detected and explains the immediate shift in community following the identified invasion point. Time lags are typically evident in invasion processes, with the effects on communities often taking several years to appear as densities of the invading organism increase (Saki et al., 2001; McCarthy et al., 2006). The ordination plots of all invaded rivers suggest that no recovery of the communities occurred following the establishment of crayfish populations, with control and invaded rivers displaying distinct trajectories. Changes to the macroinvertebrate community in invaded rivers appear to occur rapidly once crayfish densities are high enough to be detected in kick samples (Hiley, 2003). Consequently it is likely that there is a threshold effect at which impacts on the macroinvertebrate community become significant and potentially irreversible. Early detection of signal crayfish in lotic ecosystems through routine monitoring is therefore imperative in order to manage and potentially limit the implications of crayfish populations on the wider macroinverterbrate community and ecosystem.

\subsection{Taxa-crayfish interactions}

Despite differences in the response of individual taxa following invasion, the occurrence of a number of ubiquitous taxa significantly changed across all regions. The class Hirudinea is widely cited as being severely affected following crayfish invasion, typically demonstrating significant reductions in the abundance of taxa following the establishment of large crayfish populations (Stenroth and Nyström, 2003; Crawford et al., 2006; Ruokonen et al. 2014). Results from this study provide 
further evidence to support this with $G$. complanata displaying significant reductions in occurrence following crayfish invasion for both spring and autumn survey periods. The occurrence of $E$. octoculata was reduced considerably during the autumn months but displayed no significant differences during spring months (although reductions were evident). Differences in predation of these two taxa in spring months may be as a result of reproduction characteristics. Glossiphonids are the only leechs to brood and carry their young, whilst Erpobdellids form cocoons on the substrate, which may protect the young from predation during the months of March - July (Elliot and Mann, 1979). A number of reasons have been speculated as potential mechanisms to account for the reduction of Hirudinea taxa following crayfish invasion including the predatory nature of leeches and direct competition for resources. The life history of a number of Hirudinea species is strongly associated with gastropod populations as a function of their ectoparasitic nature (Elliot and Mann, 1979; Ruokonen et al., 2014), although their low mobility and soft bodies most likely results in preferential predation by $P$. leniusculus (Stenroth and Nyström, 2003).

The most widely cited taxa affected by invasive crayfish colonisation are gastropods and bivalves, with reductions in species richness, abundances and biomass widely reported (Weber and Lodge, 1990; Lodge et al., 1994; Nyström et al., 1996; 2001; Stenroth and Nyström, 2003; Dorn, 2013; Ruokonen et al., 2014). Results from this study indicate a significant effect of crayfish on Radix spp. with reductions in occurrence observed during both spring and autumn months. Gastropods have been cited as being particularly vulnerable to crayfish predation because of their limited speed of locomotion (Hanson et al., 1990; Nyström and Perez, 1998; Rosewarne et al., 2013). However, not all mollusc taxa displayed similar responses. Sphaeriidae displayed no change in response to crayfish invasion (although some reductions were evident during spring months), nor did the non-native mud snail, $P$. antipodarum. Some life history characteristics may reduce predation effects and, as a consequence of their high predation risk, many gastropod species display avoidance behaviour by migrating above the waterline for several hours (Alexander and Covich, 1991; Crowl and Covich, 1990; Turner et al., 1999), whilst others demonstrate changes to their life history through enhanced growth rates and lowered reproduction rates (Hoverman et al., 2005). Under experimental conditions $P$. antipodarum has been shown to avoid predation through increased vertical migration 
in the presence of crayfish (Haddaway et al., 2014). This avoidance mechanism would enable them to evade crayfish predation and may explain why their populations remain largely unchanged in this study despite evidence of selective predation of crayfish on gastropod species based upon handling times (time taken for crayfish to consume prey items, Crowl and Covich, 1990; Nyström and Perez, 1998).

Another taxon which is highly adaptable in their ability to evade predation and which displayed no change in occurrence for either spring or autumn months in this study was the freshwater amphipod G. pulex. This taxon has been widely cited as adopting various avoidance strategies in order to evade inter and intra-specific predation, including enhanced drift and locomotion, vertical migration and increased use of refuges (Andersson et al., 1986; McGrath et al., 2007; Haddaway et al., 2014). Consequently, it is likely that this species possesses a repertoire of strategies and defences towards predation, which potentially makes them able to evade crayfish more readily than other taxa.

Richness of aquatic insect larvae within the orders of Ephemeroptera, Plecoptera and Trichoptera (EPT richness) is one of the most commonly employed bioindicators internationally (e.g. Ligeiro et al., 2013; Tonkin et al., 2015). However, the results from this study highlight that interpretations of order level responses to disturbances associated with invasive crayfish should be undertaken with caution, especially orders supporting highly variable habitat and feeding preferences and life histories. As a result we would propose the use of greater taxonomic resolution (genus or species level if possible) to provide the appropriate information to identify and disentangle taxa-specific interactions (Monk et al., 2012).

Several studies considering the impact of crayfish, have discussed the impact of crayfish on Ephemeroptera as a whole order, rather than individual taxa (Guan and Wiles, 1998; Usio and Townsend, 2004). Results from previous research suggests that the effects on Ephemeroptera are not consistent, with some studies documenting a decrease in abundance (McCarthy et al., 2006) or selective predation by crayfish on individuals with a greater body size (Guan and Wiles, 1998), whilst others have reported an increase in abundance or no change at sites where crayfish 
have invaded (Keller and Ruman, 1998; Usio and Townsend, 2004; Crawford et al., 2006; Grandjean et al., 2011). Results from the current study indicate that as an order, individual Ephemeroptera taxa may display different responses to crayfish invasion. Within this study, the largely ubiquitous ephemeropteran genus Baetis demonstrated no change in occurrence during both spring and autumn months. This most likely reflects their relatively high mobility, thus enhancing their ability to evade crayfish predation (Peckarsky, 1996). However, not all Ephmeroptera taxa displayed positive or benign responses to crayfish invasion, with Caenis spp. demonstrating significant reductions in occurrence following crayfish invasion during both spring and autumn. This reduction may reflect habitat preferences of most Caenis spp. for fine sediment accumulations which makes them prone to ingestion or physical disturbance by foraging crayfish (Capelli, 1980; Gutierrez- Yurrita et al., 1998; Usio and Townsend, 2004; Helms and Creed, 2005).

The Trichoptera Hydropsyche spp., also displayed a significant reduction in occurrence during both spring and autumn months following crayfish invasion. The majority of feeding activity by this taxa is through net building during spring and summer months, with net construction typically representing simple open structures to permit filter feeding (Edington and Hildrew, 1995). This sedentary activity in addition to the open nature of the fixed shelter (Mackay and Wiggins, 1979) may make them preferential prey for crayfish predation, in contrast to other caseless caddisfly larvae which are freeliving and mobile such as Rhyacophilidae (Elliot, 1968) or those which are much more hidden such as Psychomyiidae in fixed enclosed tunnel like galleries (Christian et al., 2005).

\section{Conclusion}

Crayfish are considered to be influential organisms within many aquatic ecosystems, interacting with all trophic levels of the food web (Creed, 1994; Momot, 1995). The results of this study provide direct evidence to suggest that the implications of crayfish invasion are persistent and result in major changes to benthic invertebrate communities, although the effects on the community are stronger during autumn. Invasion effects are not dependent on the physical and habitat characteristics of the lotic ecosystem, with modifications to macroinvertebrate communities evident across the range of bio-geographical regions typical of lowland rivers. The specific effects 
on the invaded ecosystem are however dependent on original community composition. The resulting fauna affected and those which are responsible for the community changes observed may therefore vary between rivers. The spread of invasive taxa across the globe may also represent a significant challenge to ongoing environmental monitoring programmes. The results of this research clearly demonstrate that the predation and interaction of an invasive species with the receiving ecosystem can significantly modify aquatic community composition. These community modifications may thereby potentially affect the results of widely utilised biomonitoring indices and as a result care should be taken when interpreting routine biomonitoring data (i.e water quality, river flow or fine sediment pressures) where non-native / invasive taxa are known to be present (MacNeil et al., 2013, Mathers et al., 2016). This study highlights the value and need for further multi-scale research to fully understand the wider spatial and temporal implications of historic invasions to complement reach scale and mesocosm studies (Wilson et al., 2004; McCarthy et al., 2006). This fundamental knowledge base is needed to inform and underpin management strategies which are aimed at controlling and mitigating the effects of invasive species (Moorhouse et al., 2014).

\section{Acknowledgements}

KLM acknowledges the support of a Glendonbrook doctoral studentship and cofunding from the Environment Agency. Russ Barber, Judy England, Andy Goodwin, Katy Lee, Will Olsen and Mitch Perkins from the Environment Agency are thanked for kindly providing the data from the BIOSYS database to undertake the research. Judy England is thanked for valuable discussions relating to the outcomes of this study. We are very grateful to the anonymous reviewers for their helpful and constructive comments on the drafts of this manuscript.

\section{References}

Allan, J.D. 1981. Determinants of diet of brook trout (Salvelinus fontinalis) in a mountain stream. Canadian Journal of Fisheries and Aquatic Sciences 38: 184-192.

Alexander J.E. and Covich A.P. (1991) Predation risk and avoidance behaviour in two freshwater snails. Biological Bulletin, 180: 387 - 393.

Andersson, K. G., Brönmark, C., Herrmann, J., Malmqvist, B., Otto, C., and Sjörström, P. (1986). Presence of sculpins (Cottus gobio) reduces drift and activity of Gammarus pulex (Amphipoda). Hydrobiologia, 133: 209-215. 
Bubb, D.H., Thom, T.J. and Lucas, M.C. (2004) Movement and dispersal of the invasive signal crayfish Pacifastacus leniusculus in upland rivers. Freshwater Biology 49: 357-368.

Bobeldyk A.M. and Lamberti G.A. (2008) A decade after invasion: evaluating the continuing effects of rusty crayfish on a Michigan River. Journal of Great Lakes Research, 34: 265-275.

Carvalho, F., Pascoal, C., Cássio, F. and Sousa, R. (2016). Direct and indirect effects of an invasive omnivore crayfish on leaf litter decomposition. Science of The Total Environment, 541: 714-720.

Capelli G.M (1980) Seasonal variation in the food habitats of the crayfish Orconectes propinquas and Cambarus fodiens in Trout Lake, Vilas County, Winconsisn USA (Decapoda, Astacidae, Cambaridae). Crustaceana, 38: 82-86.

Charlebois, P.M. and Lamberti, G.A. Invading crayfish in a Michaigan stream: Direct and indirect effects on periphyton and macoinvertebrates. Journal of North American Benthological Society. 15: 551-563.

Christian, A., Spanhoff, B. and Meyer, E.I. (2005) Avoidance behaviour in the gallery construction of Tinodes unicolor (Psychomyiidae, Trichoptera) to prevent intraspecific encounters. Archiv fur Hydrobiologie, 164, 335-343.

Clarke K. and Gorley R. (2006) PRIMER v6: User manual/tutorial, Plymouth, UK: Primer-E, Ltd. 190 p.

Crawford L. Yeomans W.E. and Adams C.E. (2006) The impact of introduced signal crayfish Pacifastacus liniusculus on stream invertebrate communities. Aquatic Conservation: Marine and Freshwater Ecosystems, 16: 611-621.

Creed R.P Jr (1994) Direct and Indirect effects of crayfish grazing in a stream community. Ecology, 75: 2091-2103.

Creed Jr R.P. and Reed J.M. (2004) Ecosystem engineering by crayfish in a headwater stream. Journal of North American Benthological Society, 23: 224-236.

Crowl T.A. and Covich A.P. (1990) Predator-induced life-history shifts in a freshwater snail. Science, 23: $949-951$.

DiStefano R. J. Magoulick D.D. Imhoff E.M. and Larson E.R. (2009) Imperiled crayfishes use hyporheic zone during seasonal drying of an intermittent stream. Journal of the North American Benthological Society, 28: 142-152.

Dorn N.J. (2013) Consumptive effects of crayfish limit snail populations. Freshwater Science, 32: 1298-1308.

Dunbar M.J. Pederson M.L Cadman D. Extence C. Waddingham J. Chadd R. and Larsen S.E. (2010) River discharge and local-scale physical habitat influence macroinvertebrate LIFE scores. Freshwater Biology, 55: 226-242.

Durance I. and Ormerod S.J. (2009) Trends in water quality and discharge confound long-term warming effects on river macroinvertebrates. Freshwater Biology, 54: 388-405.

Dyer, J.J., Worthington, T.A., and Brewer, S.K. (2015) Response of crayfish to hyporheic water availability and excess sedimentation. Hydrobiologia. 747: 147-157.

Edington, J.M. and Hildrew, A.G. (2005) A revised key to the caseless caddis larvae of the British Isles, Freshwater Biological Association Publication No 53.

Elliot, J.M. (1968) The Life Histories and Drifting of Trichoptera in a Dartmoor Stream. Journal of Animal Ecology, 37: 615-625. 
Elliott J.M. and Mann K.H. (1979) A key to British Freshwater Leeches, Freshwater Biological Association Publication No 40 .

Ercoli, F., Ruokonen, T.J., Erkamo, E., Jones, R.I. and Hämäläinen, H. (2015a) Comparing the effects of introduced signal crayfish and native noble crayfish on the littoral invertebrate assemblages of boreal lakes, Freshwater Science, DOI: 10.1086/680517.

Ercoli, F., Ruokonen, T.J., Koistinen, S., Jones, R.I., and Hämäläinen, H. (2015b) The introduced signal crayfish and native noble crayfish have different effects in sublittorial macroinvertbrate assemblages in boreal lakes. Freshwater Biology, DOI: 10.1111/fwb.12601.

Flint, R.W and Goldman, C.R. (1975) The effects of a benthic grazer on the primary productivity of the littoral zone of Lake Tahoe. Limnology and Oceanography. 20: 935-944.

Fournier D.A. Skaug H.J Ancheta J. Ianelli J. Magnusson A. Maunder M.N. Nielsen A. and Sibert J. (2012) AD Model Builder: using automatic differentiation for statistical inference of highly parameterized complex nonlinear models. Optimization. Methods and Software, 27: 233-249.

Gheradi, F., Barbaresis, S., Villanellis, F. (1998) Movement Patterns of the White-clawed Crayfish, Austropotamobius pallipes, in a Tuscan Stream. Journal of Freshwater Ecology. 13: 413-424.

Gheradi F. Aquiloni L. Dieguez- Uribeondon J. and Tricarico E. (2011) Managing invasive crayfish: is there a hope?. Aquatic Sciences, 73: 185-200.

Grandjean F. Jandry J. Bardon E. and Coignet A. (2011) Use of Ephemeroptera as bioindicators of the occurrence of white-clawed crayfish (Austropotamobius pallipes). Hydrobiologia, 671: 253-258.

Goddard, J.S. (1988) Food and Feeding. In: Holdich, D.M. and Lowery, R.S. (Eds.) Freshwater Crayfish: Biology, Management and Exploitation. Chapman and Hall: London.

Guan, R.-Z. and Wiles, P.R. (1998) Feeding ecology of the signal crayfish Pacifastacus leniusculus in a British lowland river. Aquaculture, 169: 177 - 193.

Gutierrez- Yurrita P.J Sanch G. Bravo A. Baltanas A. and Montes C. (1998) Diet of the red swamp crayfish Procambarus clarkia in natural ecosystems of the Donana National Park temporary freshwater marsh. Journal of Crustacean Biology, 18: 120-127.

Gutiérrez J.L., Jones C.G. and Sousa R. (2014) Toward an integrated ecosystem perspective of invasive species impacts. Acta Oecologica, 54: 131-138.

Hannaford J. and Buys G. (2012) Trends in seasonal river flow regimes in the UK. Journal of Hydrology, 475: 158-174.

Haddaway N.R., Vielle D., Mortimer R.J.G., Christmas M. and Dunn A.M. (2014) Aquatic macroinvertbrate responses to native and non-native predators. Knowledge and Management of Aquatic Ecosystems. 415.

Hanson J.M. Chambers P.A. and Prepas E.E. (1990) Selective foraging by the crayfish Orconectes virilis and its impact on macroinvertebrates. Freshwater Biology, 24: 69-80.

Helms B.S. and Creed R.P. (2005) The effects of 2 coexisting crayfish on an Appalachian river community. Journal of the North American Benthological Society, 24: 113-122.

Hiley, P.D. (2003): The slow quiet invasion of signal crayfish (Pacifastacus leniusculus) in England prospects for the white-clawed crayfish (Austropotamobius pallipes) in: Holdich, D.M. and Sibley, P.J. (2003): Management and Conservation of Crayfish: Proceedings of a conference held on $7^{\text {th }}$ November 2002 at the Nottingham Forest Football Club, Nottingham, UK. 127-138. Environment Agency, Bristol. 
Holdich D.M. James J. Jackson C. and Peay S. (2014) The North American signal crayfish, with particular reference to its success as an invasive species in Great Britain, Ethology, Ecology and Evolution, 26: 232-262.

Hoverman J.T., Auld J.R. and Relyea R.A. (2005) Putting prey back together again: Integrating predator-induced behavior, morphology, and life history. Oecologia, 144: 481-491.

Hudina S. Hock K. Zgnec K. and Lucic A. (2012) Changes in population characteristics and structure of the signal crayfish at the edge of its invasive range in a European river. International Journal of Limnology, 48: 3-11.

IBM Corp. Released (2012) IBM SPSS Statistics for Windows, Version 21.0. Armonk, NY: IBM Corp.

Ilheu, M., and Bernardo, J.M. (1993) Experimental evaluation of food preference of red swamp crayfish, Procambarus clarkii: vegetal versus animal. Freshwater. Crayfish, 9: 359-364.

Jackson M.C. Jones T. Millidan M. Sheath D. Taylor J Ellis A. England J. and Grey J. (2014) Niche differentiation among invasive crayfish and their impacts on ecosystem structure and functioning. Freshwater Biology, 59: 1123-1135.

Johnson, M.F., Rice, S.P., and Reid, I., (2014) The activity of signal crayfish (Pacifastacus leniusculus) in relation to thermal and hydraulic dynamics of an alluvial stream, UK. Hydrobiolgia, 724: 41 - 54.

Keller T.R. and Ruman L.C. (1998) Short-term crayfish effects on stream algae and invertebrates. Journal of Freshwater Ecology, 13: 97-104.

Kouba, A., Petrusek, A. and Kozák, P. (2014) Continental-wide distribution of crayfish species in Europe: update and maps. Knowledge and Management of Aquatic Ecosystems, $\mathbf{4 1 3}$

Lagrue C. Podgorniak T. Lecerf A. and Bollache L. (2014) An invasive species may be better than none: invasive signal and native noble crayfish have similar community effects. Freshwater Biology, 59: 1982-1995.

Laize C.L.R. Acreman M.C. Schneider C. Dunbar M.J., Houghton-Carr H.A. Florke M. and Hannah D.M. (2014) Projected flow alteration and ecological risk for pan European rivers. River Research and Applications, 30: 299-314.

Ligeiro, R. Hughes, R.M., Kaufmann, P.R., Macedo, D.R., Firmianoa, K.R., Ferreiraa, W.R., Oliveiraa, D., Meloe, A.S., Callistoa, M. 2013. Defining quantitative stream disturbance gradients and the additive role of habitat variation to explain macroinvertebrate taxa richness. Ecological. Indicators. 25: 45-57.

Lodge D.M. and Hill A.M. (1994) Factors governing species composition, population size and productivity of coolwater crayfishes. Nordic Journal of Freshwater Research, 69: 111-136.

Lodge D.M. Kershner M.W. Aloi J.E. and Covich A.P. (1994) Effects of an omniviorous crayfish (Orconectes rusticus) on a freshwater littoral food web. Ecology, 75: 1265-1281.

Lodge D.M. Taylor A. Holdich D.M. and Skurdal J. (2000) Nonindigenous Crayfishes Threaten North American Freshwater Biodiversity: Lessons from Europe. Fisheries, 25:7-20.

Lodge D.M. Deines A. Gheradi F. Yeo D.C.J. Arcella T.,Baldridge A.K. et al., (2012) Global Introductions of Crayfishes: Evaluating the Impact of Species Invasions on Ecosystem Services. Annual Review of Ecology, Evolution, and Systematics, 43: 449-472.

Mackay, R.J and Wiggins, G.B. (1979) Ecological diversity in Trichoptera, Annual Reviews in Entomology, 24: 185-208.

MacNeil, C., Boets, P., Lock, K., Goethals, P.L.M. (2013) Potential effects of the invasive 'killer shrimp' 
(Dikerogammarus villosus) on macroinvertebrate assemblages and biomonitoring indices. Freshwater. Biology. 58: 1717-182.

Magoulick, D.D. (2014) Impacts of drought and crayfish invasion on stream ecosystem structure and function. River Research and Applications, 30: 1309 -1317.

Marsh T. Cole G. and Wilby R. (2007) Major droughts in England and Wales, 1800 -2006. Weather, 62: 87-93.

Martin-Smith K.M. and Armstrong J.D. (2002) Growth rates of wild stream-dwelling Atlantic salmon correlate with activity and sex but not dominance. Journal of Animal Ecology, 71: 413-423.

Mathers, K.L., Chadd, R.P., Extence, C.A., Rice, S.P. and Wood, P.J. (2016) The implications of an invasive species on the reliability of macroinverterbrate biomonitoring tools used in freshwater ecological assessments. Ecological Indicators. 63: 23-28.

Matsuzaki S.S. Usio N. Takamura N. and Washitani I. (2009) Contrasting impacts of invasive engineers on freshwater ecosystems; an experiment and meta-analysis. Oecologia, 158: 673-686.

McCarthy J.M. Hein C.L. Olden J.D. and Vander Zanden M.J. (2006) Coupling long term studies with meta-analysis to investigate impacts of non-native crayfish on zoobenthic communities. Freshwater Biology, 51: 224-235.

McGrath, K. E., Peeters, E. T., Beijer, J. A., and Scheffer, M. (2007). Habitat-mediated cannibalism and microhabitat restriction in the stream invertebrate Gammarus pulex. Hydrobiologia, 589: 155-164.

Momot W.T. (1995) Redefining the role of crayfish in aquatic ecosystems. Reviews in Fisheries Science, 3, 33- 63.

Momot W.T. Gowing H. and Jones P.D. (1978) The dynamics of crayfish and their role in ecosystems. American Midland Naturalist, 99: 10 - 35.

Monk W.A. Wood P.J. Hannah D.M. and Wilson D.A. (2008) Macroinvertebrate community response to inter-annual and regional river flow regime dynamics. River Research and Applications, 24: 9881001.

Monk W.A. Wood P.J. Hannah D.M. Extence C.A. Chadd R.P. and Dunbar M.J. (2012) How does macroinvertebrate taxonomic resolution influence ecohydrological relationships in riverine ecosystems. Ecohydrology, 5: 36-45.

Moorhouse T. P. Poole A.E. Evans L.C. Bradley D.C. and Macdonald D.W. (2014) Intensive removal of signal crayfish (Pacifastacus leniusculus) from rivers increases numbers and taxon richness of macroinvertebrate species. Ecology and Evolution, 4: 494-504.

Murray-Bligh J. 1999. Procedures for Collecting and Analysing Macroinvertebrate Samples - BT0001. The Environment Agency, Bristol; 176.

Murria C. Bonada N. and Prat N. (2008) Effects of the invasive species Potamopyrgus antipodarum (Hydrobiidae, Mollusca) on community structure in a small Mediterranean stream. Archiv für Hydrobiologie, 171: 131-143.

Nilsson E. Solomon C.T. Wilson K.A. Willis T.V. Larget B. and Vander Zanden M.J. (2012). Effects of an invasive crayfish on trophic relationships in north-temperate lake food webs. Freshwater Biology, 57: 10-23.

Nyström P (1999) Ecological impact of introduced and native crayfish on freshwater communities. In Gheradi, F., and Holdich, D.M. (Eds.) Crayfish in Europe as Alien Species. AA Balkema : Rotterdam.

Nyström P. and Perez J.R. (1998) Crayfish predation on the common pond snail (Lymnaea stagnalis): the effect of habitat complexity and snail size on foraging efficiency. Hydrobiologia, 368: 201-208. 
Nyström P., Bronmark C. and Graneli W. (1996) Patterns in benthic food webs: a role for omnivorous crayfish. Freshwater Biology, 36: 673-682.

Nyström P. Bronmark C. and Graneli W. (1999) Influence of an exotic and a native crayfish species on a littoral benthic community. Oikos, 85: 545-553.

Nyström P. Svensson O. Lardner B. Brönmark C. and Granelí W. (2001) The influence of multiple introduced predators on a littoral pond community. Ecology, 82: 1023-1039.

Parkyn S.M., Rabeni C.F. and Collier K.J. (1997) Effects of crayfish (Paranephrops planifrons: Parastacidae) on in-stream processes and benthic faunas: a density manipulation experiment. New Zealand Journal of Marine and Freshwater Research 31: 685 - 692.

Peay S., (2003) Monitoring the White-clawed Crayfish, Austropotamobius pallipes. Conserving Nature 2000 Rivers, Monitoring Series No. 1. English Nature, Peterborough, 52pp.

Peckarsky B.L. (1996) Alternative predator avoidance syndromes in stream-dwelling mayflies. Ecology, 77: 1888-1905.

Ponder W. (1988) Potamopyrgus antipodarum- A molluscan coloniser of Europe and Australia. Journal of Molluscan Studies, 54: 271-285.

Pysek P. Richardson D.M. Pergrl J. Jarosik V. Sixtova Z. and Weber E. (2008) Geographical and taxon bias in invasion ecology. Trends in Ecology and evolution, 23: 237-244.

R Development Core Team (2014). R: A language and environment for statistical computing. $R$ Foundation for Statistical Computing, Vienna, Austria. ISBN 3-900051-07-0.

Ricciardi A. (2007) Are modern biological invasions an unprecedented form of global change? Conservation Biology, 21: 329-336.

Rosewarne P.J. Mortimer R.J.G. and Dunn, A.M. (2013) Size-dependent impacts of the endangered white-clawed crayfish (Austropotamobius pallipes) (Lereboullet) on the littoral community. Knowledge and Management of Aquatic Ecosystems, 409. DOI: 10.1051/kmae/2013047

Ruokonen T.J. Karjalainen J. and Hamalainen H. (2014) Effects of an invasive crayfish on the littoral macroinvertebrates of large boreal lakes are habitat specific. Freshwater Biology, 59: 12-25.

Sakai, A. K., Allendorf, F. W., Holt, J. S., Lodge, D. M., Molofsky, J. et al. (2001) The population biology of invasive species. Annual Review of Ecology and Systematics, 32: 305-332.

Sala O. E. Chapin F.S, Armesto J.J. Berlow, E. Bloomfield J. Dirzo R. Huber- Sannwald E. Huenneke L. Jackson, R.B. Kinzig A. Leemans R. Lodge D.M. Mooney H.A. Oesterheld M. Poff N.L. Sykes M.T. Walker B.H. Walker M. and Wall D.H. (2000) Biodiversity scenarios for the year 2100. Science, 287: 1770-1774.

Simberloff D. Martin J. Aronson J.-L. Courchamp F. Galil B. Garcia-Berthou E. Genovesi P. Maris V. Pascal M. Pysek P. Sousa R. Tabacchi E. Vila M. and Wardle D. (2013) Impacts of biological invasions-what's what and the way forward. Trends in Ecology and Evolution Trends in Ecology and Evolution, 28: 58- 66 .

Skaug H. Fournier D. Bolker B. Magnusson A. and Nielsen A. (2014) Generalized Linear Mixed Models using AD Model Builder. R package version 0.8.1.

Sousa R., Freitas F., Nogueira A.J.A., Mota M. and Antunes C. (2013) Invasive dynamics of the crayfish Procambarus clarkii (Girard, 1852) at the international section of the River Minho (NW of the Iberian Peninsula). Aquatic Conservation: Marine and Freshwater Ecosystems, 23: 656-666.

Stenroth P. and Nyström P. (2003) Exotic crayfish in a brown water stream: effects on juvenile trout, invertebrates and algae. Freshwater Biology, 48: 466-475. 
Strayer D.L. (2010) Alien species in fresh waters: ecological effects, interactions with other stressors, and prospects for the Future. Freshwater Biology, 55: 152-174.

Tonkin J.D., Shah D.N., Kuemmerlen M., Li F., Cai Q., Haase, P., Jähnig, S.C. 2015. Climatic and catchment-scale predictors of Chinese stream insect richness differ between taxonomic groups. PLoS ONE 10: DOI: 10.1371/journal.pone.0123250

Turner A.M., Fetterolf S.A. and Bernot R.J. (1999) Predator identity and consumer behavior: differential effects of fish and crayfish on the habitat use of a freshwater snail. Oecologia, 118: 242247.

Twardocleb L.A., Olden J.D., and Larson, E.R. (2013) A global meta-analysis of the ecological impacts of non-native crayfish. Freshwater Science, 32: 1367-1382.

Usio N. and Townsend C.R. (2004) Roles of crayfish: Consequences of predation and bioturbation for stream invertebrates. Ecology, 85: 807-822.

Weber L.M. and Lodge D.M. (1990): Periphytic food and predatory crayfish: relative roles in determining snail distribution. Oecologia, 82: 33-39.

Wright J.F. Clarke T. Gunn R.J.M. Kneebone N. and Davy-Bowker J. (2004) Impact of major changes in flow regime on the macroinverterbate assemblages of four chalk stream sites 1997-2001. River Research and Applications, 20: 775-794.

Wilson K.A. Magnuson J.J. Lodge D.M. Hill A.M. Kratz T.K. Perry W.L. and Willis T.V. (2004) A longterm rusty crayfish (Orconectes rusticus) invasion: dispersal patterns and community change in a north temperate lake. Canadian Journal of Fisheries and Aquatic Sciences, 61: 2255-2266.

Worrall T.P. Dunbar M.J. Extence C.A. Laize C.L.R. Monk W.A. and Wood P.J. (2014) The identification of hydrological indices for the characterization of macroinvertebrate community response to flow regime variability. Hydrological Sciences, 59: 645-658.

Xu, J., Wen, Z., Gong, Z., Zhang, M., Xie, P. and Hansson, L-A. (2014) Seasonal Trophic Niche Shift and Cascading Effect of a Generalist Predator Fish. PLOS one. 7: doi:10.1371/journal.pone.0049691. 